\title{
Conceptualizing Core Practices for Professional Development of Novice Mentors
}

\author{
Samina Naseem* \\ Paul A. Crutcher**
}

\begin{abstract}
Purposeful and effective professional development of teacher mentors is often a proposed solution in many of the present debates about education, including teacher quality, teacher retention, and the student achievement gap. The literature about teacher mentoring suggests that if mentors in teacher education programs do not have significant professional development on mentoring, even a thoughtfully organized formal induction program can be ineffective in preparing good teachers, undermined by an unprepared mentor. The purpose of this conceptual paper is to propose a framework of professional development for veteran teachers who are to become mentors. Our framework will have a three-fold effect. The framework is designed to (a) develop or strengthen supportive and collaborative partnerships between schools and teacher education programs; (b) prompt veteran teachers to identify, share, and deconstruct their teaching practices with colleagues and teacher educators; and (c) scaffold teacher learning into research on and best practices in effective mentoring. Ultimately, the framework's aim is to structure the preparation of effective teacher mentors, who will go on to have positive impacts on interns and novice teachers' long-term successes. Notably, based on the research, our Professional Development (PD) framework is situated in schools, about subject area knowledge, and focused on mastery of mentoring skills.
\end{abstract}

Keywords: Mentoring, professional development, novice mentors, core practices

*Assistant Professor, Department of Education, Fatima Jinnah Women University Rawalpindi-Pakistan 46000

** Assistant Professor of English and English Education

Interim Director of English Education University of Arkansas at Little Rock, English Department. 


\section{Introduction}

Melinda is a first-year primary school teacher who has started her career quite successfully. A veteran colleague, Barbara, doles out ideas and advice, and is certainly a part of Melinda's success. Yet this case study in the common, defacto mentor-mentee relationship (by Santrock, 2013) is also more complicated. Barbara, it turns out, "was happy to play the role of mentor as long as Melinda accepted the role of eager novice," and the two disagreed about state test preparation, parent involvement, "fun" and enthusiasm in classrooms, quality assessments of teaching, and more (Santrock, 2013, p. 214). Melinda and Barbara were sometimes defensive, sometimes patronizing, and so on, and these disagreements highlighted at least one thing about this common relationship in teacher preparation and induction-Barbara lacked any explicit training or knowledge about mentoring, and that dearth limited her ability to prepare Melinda for long-term teaching goals and professional success. We might say Barbara failed the time-tested mantra in composition and elsewhere-_"show, don't tell."

Of course, we understand that purposeful and effective mentoring includes a great deal of both showing and telling, and that veteran teachers (including Barbara) do too, since that principle underpins teaching. We might follow mentoring scholar Feiman-Nemser (2001a, p. 18) through her description of mentoring, and it's doubtful we would get anything but agreement from novice and veteran teachers. She writes that "exemplary" mentors attend to beginning teachers' present concerns, questions, and purposes without losing sight of long-term goals for teacher development. They interact with novices in ways that foster an inquiring stance. They cultivate skills and habits that enable novices to learn in and from their practice. They use their knowledge and expertise to assess the direction novices are heading and to create opportunities and conditions that support meaningful teacher learning in the service of student learning.

Despite the intuitive import of Feiman-Nemser's description, it's notable that even exemplary veteran teachers do not necessarily have the skills to provide that kind of support. Mentoring and teaching may be related (e.g., they both are undermined by unexamined "apprenticeship of observation," see Borg, 2004), and if we are to concede that vigorous and substantial work goes into becoming an exemplary teacher, we should certainly agree that training and deliberate action is necessary for the teacher to study and practice how to become a mentor. In this way, 
experienced, in-service, "veteran" teachers are not necessarily exceptional or intuitive mentors, even though they may be incredible teachers.

Based in part on the common experience of the sort between Barbara and Melinda in teacher preparation and induction today, this paper proposes a framework of professional development (PD) for veteran teachers who are to become mentors. For the purposes of this paper, we define professional development as ongoing, continuous, embedded in teachers' practices, participatory in nature that not only improves teachers' practices, but also results in sustainable learning communities (Adler, 2000; Borko, 2004; Lave \& Wenger, 1991; Little, 2002). Our framework should have a three-fold effect. It would (a) develop or strengthen supportive and collaborative partnerships between schools and teacher education programs; (b) prompt veteran teachers to identify, share, and deconstruct their teaching practices with colleagues and teacher educators; and (c) scaffold teacher learning into research on and best practices in effective mentoring. Ultimately, the framework's aim is to structure the preparation of effective teacher mentors, who will go on to have positive impacts on intern and novice teachers' long-term successes. Notably, based on the research, our PD framework is situated in schools, about subject area knowledge, and focused on mastery of mentoring skills.

We understand and use the term veteran as the idiomatic juxtaposition to novice. Veteran teachers in this sense are therefore teachers who through disposition, effort, and experience have developed self- and verifiable-efficacy, professional maturity, and expertise. This idiomatic of a veteran seems to align with Feiman-Nemser's discussion of veteran teachers and mentors (2001).

The previous section described the importance of PD for novice mentors. Next, we give details of why PD is important, and we follow that with a framework that shows how to best design the PD.

\section{Why PD for Mentors?}

Becoming a teacher is challenging at both elementary and secondary levels (Gustafson, Guilbert, \& MacDonald, 2002; Luft, 2009). Rigorous coursework in teacher education programs addressing pedagogies may not be enough to prepare teacher candidates to teach subject matter effectively. Adams and Krockover (1997) believe that "Having completed a course does not guarantee adequate knowledge of how to instruct a concept" (p. 647). Novice teachers might go through 
the difficulty of transitioning content to effective instructions because of the nature of teaching and the multiplicity of tasks faced by teachers. Mentoring could provide experiences that help novices to understand scientific concepts in-depth and in context; to practice new teaching strategies learned during coursework in Teacher Education (TE) programs; and to recognize their potential while understanding and developing themselves as teachers and professionals. Though novices have observed their teachers as students and have taken courses about teaching, this does not mean that they know everything that a teacher does because they have not experienced it or have not practiced what experienced teachers have been doing for years (e.g., Crutcher \& Naseem, 2015). Novice teachers require specialized guidance and support to address their pedagogical and content needs. This guidance is likely to be provided by professionally-developed mentors.

Teacher mentoring is a crucial focus and often a proposed solution in the many of the present debates about education, including teacher quality, teacher retention, and the student achievement gap. The literature on mentoring (e.g., Moir et al., 2009) suggests that if mentors in teacher education programs do not have significant professional development on mentoring, for instance, even a thoughtfully organized formal induction program can be ineffective in preparing good teachers, undermined by an unprepared mentor. Mentorship develops over time, in large part because teachers must understand and experience a transition from being a teacher to being a teacher educator. Furthermore, Schneider (2008) argues that guided opportunities for mentors' learning are also essential. Orland (2001) points out that novice mentors, even though they may be experienced teachers, go through the same trajectory of development as novice teachers do when they are learning to teach. In addition, Orland argues that being a good teacher of children and young people does not necessarily make one a good mentor, because teaching children and young people is appreciably different from reflecting and deconstructing one's own teaching practice in order to share the "what," "why," and "how" of a teaching practice with a novice. Teachers must induct themselves consciously into a different teaching context to become a mentor.

In the beginning years of mentoring, teachers may struggle with the requisite tasks of the effective mentor. For example, Feiman-Nemser (2003) writes that good classroom teachers may not know how to make their thinking visible, explain the principles behind their practice, or break down complex teaching moves into components understandable to a beginner. Nor do they necessarily know how to design an 
individualized curriculum for learning to teach that is tailored to the specific strengths and vulnerabilities of a particular novice in a specific context (p. 5).

Feiman-Nemser (2003) adds that the professional development of mentors must be taken "seriously" by induction programs to develop "critical conversation and joint work" skills in veteran teachers (p. 5). That sort of investment in the professional development of mentors is especially designed to renew and retain veteran teachers in ascribed roles as teacher educators. This claim is further supported by Moir, Barlin, Gless, and Miles (2009), who also emphasize that we should not assume that one who knows how to teach also knows how to mentor. Moir et al.(2009) therefore suggest that mentors' professional development is "carefully chunked and sequenced" (p. 53) to make it match as closely as possible to the needs of the mentoring process and novices.

Similarly, other studies have found that mentors' practices are influenced by professional development opportunities, and they have suggested enunciating a knowledge base and relevant professional mentor development (Athanases \& Achinstein, 2003; Stanulis, 1994; Stanulis \& Ames, 2009; Stanulis \& Floden, 2009). Researchers have argued that mentoring is more than a "buddy" type of support. If mentors are not prepared for their job as mentors, they can become a "buddy" who advises and explains school procedures but rarely observes and provides feedback about teaching and learning (Stanulis \& Floden, 2009).

Indeed, Feiman-Nemser (2001b) argues that mentors should be far more than supportive buddies of interns or novices-she expects mentors who are not only "educational companions" but are also "agents of change" (p. 1032; an idea also in Guskey, 1986). That is, according to FeimanNemser (2001b), well-trained mentors not only help novices to cope with procedural and immediate problems, but also develop their critical thinking, encourage them to become a part of "shared inquiry" and organize opportunities in which novices can interact with more experienced teachers and can have "conversations about teaching" (p. 1032).

\section{Framework for Professional Development}

The framework for PD we advance here is intended to embody cumulative ideas about mentoring and teacher education, particularly those detailed above. In the previous sections, we have discussed the "what" and "why" of mentoring (i.e., what is needed to improve teaching and why is it important to provide PD for novice mentors). In this section 
we discuss "how" an effective PD can be organized by conceptualizing core practices.

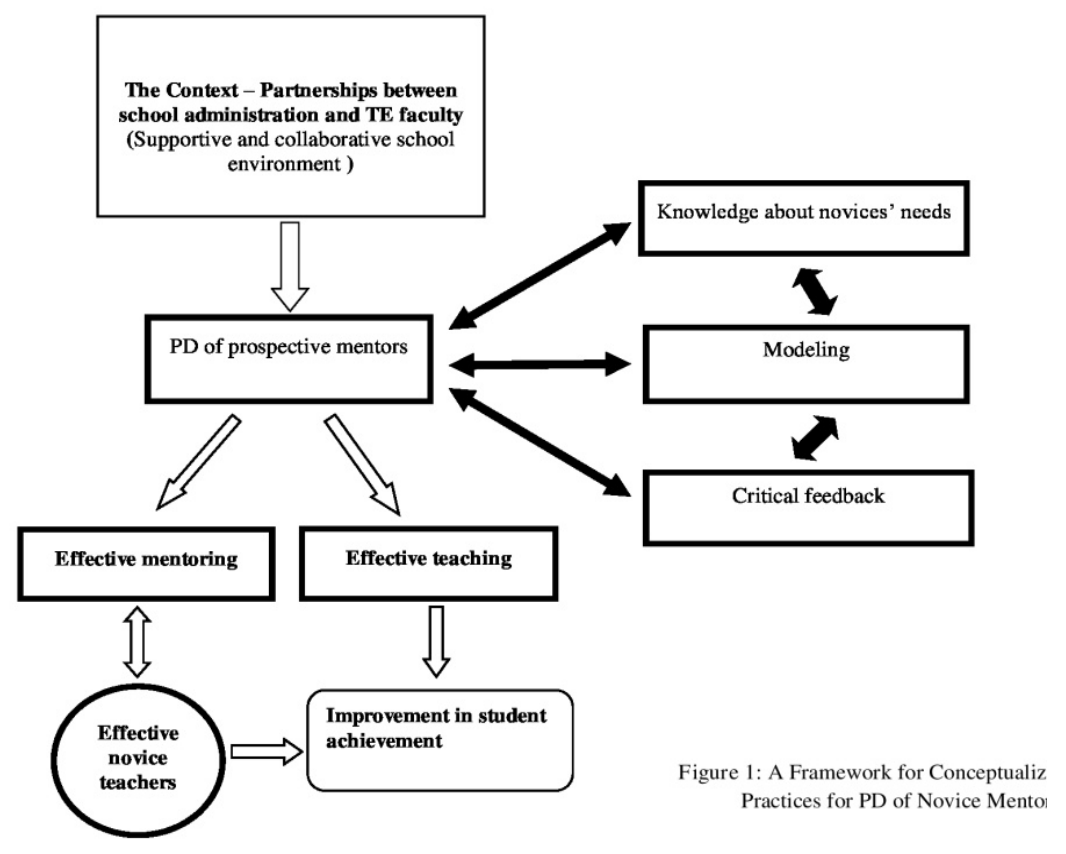

Figure 1 illustrates our proposed framework of PD for novice

mentors.

\section{The Context of PD}

Many researchers call for partnerships and strong communication between colleges of education and partner schools to provide more learning opportunities. For instance, Grossman (2008), in her response to critics of teacher education programs, asserts that programs need to develop a common language and a common set of values to be taught to novices. Stigler and Hiebert (2004), in their report on the TIMMS video studies they conducted to examine teaching practices of mathematics teachers in high achieving countries, state that the lack of "shared language" hinders dissemination of "professional knowledge" (p. 13) among teachers. Darling- Hammond (2009) and Zeichner (2010) 
highlight disconnects between courses taught in teacher education programs and schools. Zeichner (2010) takes a step further and suggests the creation of "hybrid spaces" to connect courses taught in universities with field experiences (something that can also be seen in Borko, 2004). But many researchers have not identified how to develop hybrid spaces, what they should look like, or what kinds of learning should be emphasized in them. Nor have they addressed what should be done, based on research results, to bridge the gap between theory and practice or to provide learning opportunities to develop independence and greater professional autonomy in novice teachers-in other words, how to support "continuity" between what novices learn in teacher education programs and from practice in schools (Latta \& Field, 2005, p. 651).

We argue that the existing literature talks about what and why some practices are significant for novices' teaching-learning experiences, but the how has been missing. The proposed framework suggests a way to support "continuity" and "how" to bridge the gap between theory and practice. We also argue that the current literature about professional development of mentors revolves around the ideas appraised by teacher educators and researchers. The literature ignores the "cultural baggage" (Britzman, 1986), or socialized ideas about teaching and learning that novice mentors bring with them in PDs and also ignores the strengths novice mentors have developed as veteran teachers. Our framework takes in account the strategies novice mentors feel competent about (Bell \& Gilbert, 1996; Clark, 1992; Hargreaves \& Fullan, 1992) and provides opportunities to novice mentors to choose mentoring practices that are "close to [their] hearts... and choose professional development activities [and teachers] to celebrate, improve, and show off the things [teachers] can do" (Clark, 1992, p. 80). Moreover, the framework brings teacher educators, novice mentors, and novice teachers on one platform where they can share their ideas thoughtfully and initiate constructive conversations (Schneider, 2007).

Principals play significant roles in creating supportive and collaborative structures to help teachers to learn and implement their learning within the school. In conclusion to her study about the role of principals as professional development leaders, Drago-Severson (2007) concludes that when principals emphasize the significance of creating structures within the school and attends both to individual and collective needs of teachers, they create an environment where teachers gradually take ownership of the practices, thus making them an integral part of the school. Emphasizing supportive school contexts and cultures for teacher learning, Drago-Severson (2007) adds, "individual school context and 
culture matter when contemplating ways to adapt these practices to support greater collaboration and learning" (p. 116, emphasis in original).

Professional development opportunities are requisite for improving teaching practices, and TE programs play an important role in those opportunities. One issue pertaining to professional development is that teacher educators have to cater to two populations of mentors. Because of the high turnover rate, experienced and interested teachers are increasingly difficult to find, so TE programs will have to organize professional development courses to prompt experienced teachers to update their knowledge about new strategies and to encourage and train less experienced teachers as mentors for newly inducted teachers or interns. Clarke (2001) suggests that teacher educators "reconsider professional-development opportunities for co-operating teachers, with different emphases for the two distinctly different age groups: an introduction to advisory practices for younger teachers and a review and analysis of advisory practices for more experienced advisors" (p. 243). This differentiation will help university teachers and principals organize workshops according to the needs of prospective teacher mentors and to the extent to which these mentors actually need preparation.

\section{The Content and Focus of PD: The Core Practices}

In the literature about effective mentoring, the following three areas are highlighted as key to make teaching of novice teachers effective in general: knowledge about the needs of novice teachers, critical feedback/reflection, and modeling.

As Windschitl, Thompson, and Braaten (2009) conclude, without having "an identifiable set of core practices" by teacher educators and novices, for instruction, the measures taken by TE programs to improve instruction will continue to be fruitless, it will be "isolated, individual, and haphazard" (p. 2). Similarly, we reason that if there is no identifiable set of core practices for the professional development of teacher mentors, all measures for improving instruction in general, and novices' teachinglearning experiences will continue to be "isolated, individual, and haphazard." These strategies can be considered as "central tasks" (Feiman-Nemser, 2001b) or "core practices" (Windschitl, Thompson, \& Braaten, 2009) for mentors, and the content and focus of PD. 


\section{Knowledge about the Needs of Novices}

The literature on mentoring shows that mentors need knowledge about strengths and weaknesses of novices. For instance, Harrison, Dymoke, and Pell (2006) argue that the learning process of "teachers must be about their practice, must be built on experiences derived from their practices" (p. 1055, emphasis in original). They add that principles of active learning equally apply to the teacher as a "professional learner," and they emphasize that TE should adopt a "learner-centered" approach through mentoring (p. 1055). Other researchers have also indicated that mentors need to know how to employ a range of instructional strategies, how to recognize their presence or absence in a new teacher's work, and how to coach to increase their use of them as appropriate (Athanases \& Achinstein, 2003; Carver \& Katz, 2004).

What we detail here can intersect in the literature with practical knowledge. We understand that the term practical knowledge usually refers to knowledge that "motivates to act in a certain way" (Lumer, 2010, p. 1), to teachers' knowledge and beliefs about their own teaching based on their experiences (Driel, Beijaard, \& Verloop, 2001; Francis, 1995) particularly regarding skill-based knowledge and beliefs. We understand, conversely, that knowledge about the needs of teacher candidates is a much more tangible point, referring to practical things teachers and novices are doing in classrooms, ways they are performing pedagogy. Carver and Katz (2004), for instance, describe knowledge about the needs of Karen: "Entering teaching after a successful engineering career, [she] has strong subject matter knowledge but struggles to present instructional material in an engaging, age-appropriate manner. She also finds it difficult to develop rapport with her high school students" (p. 450). In other words, we position practical knowledge as teachers' ability to integrate Vine or Twitter into their teaching or teachers believing that humor is an important part of pedagogy and student engagement, whereas what we find in the literature and discuss in the paper is teachers' understanding when to talk, move or eat.

Regardless, PD should be mentor-centered, and while organizing PD for mentors, it is significant that the PD content is based on strengths and weaknesses of mentors, or for instance, on tangible things Karen might do to build rapport with her students. Mentors' strengths should be enhanced and steps should be taken to help mentors overcome their weaknesses. PD should focus on helping mentors develop dispositions and decision-making that would teach them to guide novices to focus on student learning in varying degrees. 


\section{Critical Feedback/Reflection}

Critical feedback and reflection is defined by Stanulis (1994) and Ottesen (2007) as feedback that helps novices to improve their teaching, enhance their ability to think about and think beyond their teaching, and to analyze, reflect, and deconstruct their teaching. Research has shown that critical reflection is an important tool of mentoring (Feiman-Nemser, 1998), and giving feedback is the most crucial part of mentoring (Stanulis \& Ames, 2009; Carver \& Katz, 2004; Andrews \& Quinn, 2005). According to Fletcher (2000), critical feedback depends on two things: the "accurate and detailed observation of practice" and "an understanding of the trainee as an individual learner" (p. 82, emphasis added). This statement further supports the idea of mentors having knowledge about novices and providing feedback according to novices' needs rather than providing all novices with the same kind of feedback. The feedback must be very specific to issues observed by mentors that are related to beginning teachers' teaching-learning practices. For instance, if the beginning teacher is experiencing difficulty with content pedagogy, mentor's feedback should address content pedagogy (i.e., rather than anything else that might be about teaching in general, like teaching styles or classroom discipline).

Similarly, during the PD, mentors should be given critical feedback about their teaching and mentoring practices. Helping mentors to reflect on teaching decisions and to think forward to theorize how and why they make decisions prompts mentors to internalize and value reflective practices and to guide their future mentoring and teaching. Discussions should challenge their thinking, providing them opportunities to consider new perspectives about teaching, mentoring, and learning, but also compelling them to thoughtfully rationalize their own ideas and practices. It should involve finding solutions for specific and general problems especially those which are common to all contexts (e.g., differentiated instruction, generally, an intern's emotional outburst at a faculty lounge chat about Breaking Bad).

Teacher educators and mentors can use specific tools to develop critical reflection skills. One such tool used by researchers (e.g., Sherin \& van Es, 2009) is a teaching video. Sherin and van Es used excerpts from teachers' classroom videos to help novice teachers learn to notice and critically analyze what they see. Their findings suggest change in the nature of teachers' comments from general to more specific about what they notice. Similarly, keeping a daily reflective journal can also be an 
effective tool for improving critical reflection skills (Schwille, 2008). However, we argue that teacher educators and mentors must read daily reflections and ask questions leading novice teachers to think a step further. If a student teacher writes that she had a great day or her students were engaged in the classroom, asking her what made her day "great" or why she thinks her students were engaged will help her to look for evidence rather than simply relaying experience and opinion.

\section{Modeling}

The literature highlights the significance of modeling (e.g., Boreen \& Niday, 2000; Mills, Moore, \& Keane, 2001). Segall (2001) and Korthagen, Loughran and Russell (2006) write that innovative theories and teaching-learning approaches be practiced and experienced by student teachers and modeled by teacher educators and mentors. Modeling exemplifies what teaching strategies look like and how to implement them. Modeling or demonstration teaching must be "planned events, and prepared for by identifying what [student teachers] should watch for and what questions [student teachers] should ask about the mentors' thinking and decision making" (Schwille, 2008, p. 148). Modeling by mentors of various teaching strategies, such as reflection, using several sources for teaching, and decision-making, helps novices identify, understand, and adopt these teaching strategies. For instance, the results of an experimental study done by Stanulis and Floden (2009) show that many beginning teachers learned how to collect data to analyze their students' work while working closely with their mentors. Importantly, novices' ability to reflect grows when their mentors ask them to reflect on and deconstruct the mentors' teaching (Cherian, 2007; Feiman-Nemser, 2001a; Stanulis, 1994).

However, Segall (2001) and Korthagen, Loughran, and Russell (2006) also argue that many teacher educators and mentors do not model what they teach. Therefore, novices do not have any example to follow (beyond the distorted ones already present; see Borg, 2004). Similarly, if PD is to be successful, teacher educators should model strategies like conducting content-focused discussions in classrooms, asking good questions, providing feedback to students in a constructive way, and using information to improve instructions. Mentors should do the same with novices, after learning in the same way-from models.

The content of PD, these three strategies are certainly interrelated. Knowledge about the audience of the workshop would be beneficial for teacher educators to select content and activities for the PD based on the 
strengths of the veteran teachers. This, in turn, helps to build on strengths and weaknesses of the teachers through providing opportunities and critical feedback. Having critical discussions about subject matter and instructions would provide knowledge about novice mentors, which could also be useful to identify teaching strategies the mentors use and ideologies they follow. Thus, teacher educators could model how to use and develop expertise and could also involve veteran teachers and use the teaching experiences they had been successfully using to model in front of their colleagues. The same cycle of teaching and learning would then be used among mentors and novice teachers. As mentors and teacher educators learn from each others' teaching and research experiences, similarly, working with novices becomes a reciprocal opportunity for both novices and mentors to learn. Hence, the purposeful and effective start is PD.

\section{Implementation and Logistics}

Authors belong to two different worlds and work in two different teaching contexts-cultural support, broader politics, educational, and policy stability. However, we believe that the flexibility of the proposed framework allows it to be adapted to and implemented for TE programs in varied contexts. The time required for adaptation and implementation will be different according to context, depending on the availability of existing TE, PD, and university-school partner structures.

In highly-structured TE contexts and in countries with mentoring programs in place (e.g., the US, UK, Japan), implementation of a PD for developing veteran teachers into exemplary mentors is relatively straightforward. Although there is a bureaucracy to follow, one can find a number of researchers, administrators, and teachers understanding the need of mentoring and its importance in general. In the US, for instance, Moir et al. (2009) have been providing PD to mentors for past two decades and have been doing research with mentors; our framework could be implemented into such existing partnerships, TE curricula, and research.

However, in contexts and in countries which lack formal mentoring programs and those existing structures or are in a phase of finding appropriate PD frameworks (e.g., Pakistan, Saudi Arabia, Nepal) teacher educators must fundamentally work to create a supportive culture for mentoring and for PD. In short, knowledge and support for mentoring and PD, generally, must be built. Such creation begins by having discussions with principals about mentoring and its importance as a two- 
way PD opportunity for both in-service and pre-service teachers. As explained earlier in this paper, principals play a crucial role in designing not only supportive contexts for mentoring, but also for setting up mentoring programs and for the requisite approval of higher education authorities. In these contexts, it is also worth noting that politics can have radical and immediate effects on education. This lack of stability and pressure effects faculty, administrators, school-university partnerships, and structures (like mentor PD) — and can negatively impact interest in reform or change.

In Pakistan, mentoring is not a new phenomenon. We understand that research into mentoring is carried out around the country, and yet it is unfortunate that the work is either not published or is not as easily accessible as in countries like the US or UK. Mentoring studies in a Pakistani context, such as Ali (1996) and Andrabi, Khan, Khan, and Naseer (2012) underscore the value of mentoring for professionally supporting in-service teachers to improve their teaching. However, the public schools catering to the largest population of teachers and students are considerably unfamiliar with mentoring and are hesitant to let student teachers teach in these classes. In the past two years, the first author, Samina, has experienced the lack of interest from most of the veteran teachers in supervising student teachers during teaching practicum. She has worked with principals and teachers of government schools and has created awareness about the importance of mentoring and its benefits for in-service teachers. Few veteran teachers sit in the classrooms while student teachers teach and give feedback to them. However, written feedback is missing and, more importantly, teachers focus more on the content missed by student teachers and discipline issues rather than how the content was taught and school students' learning. There is a lot of work to be done especially with respect to the three core practices mentioned in the framework. First, PD of school teachers and principals is in the pipeline during the coming academic year. This PD will be the first step toward creating schools as 'supportive contexts' for student teachers' learning in the coming years. In terms of implementation, logistics, and assessment, there are a number of crucial metrics researchers, like the first author, would test to determine mentoring and PD efficacy; these are also discussed below. 


\section{Discussion and Conclusion}

The PD framework we propose supports the idea of mentors being ready to learn and being responsive to the needs of novices. The strategies of the PD develop skills in mentors they could use to provide opportunities to novices to learn from their teaching and according to their needs. However, it also takes into account the context and content, which are significant aspects for effective teaching and improvement in students' achievement. Because the framework is for the PD of mentors, it also refers to taking into account needs of teachers who want to become mentors. Again, the role defined by Feiman-Nemser (2001a) is very different from Barbara's role in helping Melinda learn to teach. Barbara was more like a buddy (Stanulis \& Floden, 2009), who provides help when needed but does not offer guidance that is required to improve teaching practices such as suggested by researchers. Focused PD of the sort we detail in this paper would encourage veteran teachers to become teacher educators and help them to understand how to work and teach with adults.

PD generally is not without critics and thoughtful critique, yet we believe our work in this paper and with the framework address the most prominent and noteworthy critiques of PD. Drago-Severson (2007), for instance, argues that principals are rarely involved in PD or the education of teachers (or teachers as mentors) in their schools and communities. We address that critique above, in context, primarily by integrating Drago-Severson's rationale for including principals. Conversely, PD critiques include indictments of teachers, who can work in isolation and do not share (Ingersoll \& Strong, 2011). Our framework sees principals as assets, but it absolutely requires teachers to share, collaborate, and to learn from one another.

Ball and Cohen (1999) discuss the problem of a lack of coherent curriculum or pedagogy in PD, and we answered above with a content section that is built on a foundation of existing research. Ball and Cohen also note the tendency of PD to be didactic and uninterested in the knowledge or experiences of teachers. Similarly, Bullough Jr (2009) details ineffective PD and teacher education that focuses primarily on new practices, regardless of those practices' support in the research or proved efficacy. Our framework avoids being prescriptive or didactic, and is thoroughly founded on utilizing PD teacher ideologies and practices as catalyst and specific content. Indeed, practices discussed in the PD framework we propose are neither new nor lack vetting (after all, 
they've been tried, used, or inculcated by the very teachers learning from one another in the PD). We suggest that our approach to these critiques of PD also follows and supports Kardos, Johnson, Peske, Kauffman, and Liu (2001) in their concept of an integrated professional culture.

Two lines of critique are more difficult to tackle and are not countered by our PD framework. To the argument that PD is a drain of time and resources, particularly in the fiscally troubled public sector of education, for example, we add our voices to Feiman-Nemser's (2001a) cogent counterpoint, one we think extends to all countries: "If teaching is the profession that shapes America's future...then investing in new teacher development and the development of teachers' mentors is an investment in that future" (p. 29). To the critique that PD practices and learning are rarely, if ever, sustained beyond the explicit PD term, we implore teacher educators and teachers to consider the alchemy in their own ideologies and practices. Without doubt, teachers take things away from formal education (like PD), and those things become part of their identities. We also point to research that evidences secondary school faculty adopting the mentoring PD strategies long-term (Woloszyk, 1992).

Beyond answering critiques of PD, we also wanted to establish some of the ways that our framework meets criteria in the literature for excellent PD models. Ball and Cohen (1999) see that strong PD prompts teachers to "reconsider their current practices and to examine others, as well as to learn more about the subjects and students they teach" (p. 3), which ours certainly does, and our framework meets these Ball and Cohen criteria: involving teachers in learning rather than telling them what to do and how to do it; providing teachers enough time to "reconsider" their current practices, underscoring the duration of professional development; facilitating the watching of others teach; providing opportunities to learn about the subject they teach, to be content-focused; and exploring ways to understand their students and take account of their thinking.

Desimone (2009) has put forth five critical features of effective PD. Of Desimone's five critical features of effective PD, our framework captures four: content focus, active learning, coherence, and collective participation. The fifth is duration, something again that we hope for and that the literature indicates is possible. Finally, and perhaps summatively, Adler (2000) writes that PD "is usefully understood as a process of increasing participation in the practice of teaching, and through this participation, a process of becoming knowledgeable in and about teaching" (p. 37), a process we believe should be clear in our framework. 
In conclusion, the three strategies discussed in the framework are important in improving the quality of mentoring practices of mentors and teaching-learning experiences for novice teachers. On the one hand, these elements help mentors reflect and deconstruct their own teaching practices and prepare them to share with novices; on the other hand, the same practices also prevent novices from learning to teach in isolation and provide them opportunities to integrate themselves in the communities of practice they work with and learn from. Feiman-Nemser (2001b) cautioned that mentoring practices sometimes reinforce "traditional norms and practices rather than promoting more powerful teaching" (p. 1031). However, we presume that if there is continuous collaboration between the two main stakeholders, schools and TE programs, and if they understand each others' needs and provide professional development opportunities to mentors accordingly, then there is a stronger possibility that mentoring will convert teachinglearning experiences to "powerful teaching."

\section{Directions for Future Research}

The PD framework outlined here presents a variety of opportunities for future research. Our framework emphasizes the novicementor centered PD (i.e., "working with" mentors rather than "working on" them [Ward \& Tikinoff, 1976]). We hope that the framework stimulates a renewed interest in exploring the effectiveness of the mentoring practices mentioned in this paper and literature in new contexts and countries.

Furthermore, novice mentors' beliefs and attitudes towards mentoring may play a significant role in the sustainability of their learning during the PD. Therefore, research that documents change in novice mentors' beliefs about teaching, learning, and mentoring can provide useful insights for teacher educators.

Most importantly, this PD specifically focuses on core disciplinary practices, and offers researchers a potentially more effective training for implementation and study. Paired with subject-area knowledge, researchers could explore and document how teachers learn-how they become and advance as novice mentors (e.g., if the advancement follows the "learning to teach" model, as suggested by Orland [2000]).

Assessing the success and efficacy of the PD might follow Guskey's (2000, pp. 82-85) five metrics of evaluation-novice mentors' reactions to the experience, their learning, organizational support, use of 
new knowledge and skills, and the learning outcomes for mentors' students. To measure mentoring and teaching effectiveness, a number of researchers from the field of education and nursing have used different scales or have identified particular characteristics (e.g., Berk, Berg, Mortimer, Moss, \& Yeo, 2005; Darling-Hammond, 2010; Moir, 2010; Moir, et al., 2009). Berk et al., (2005), for instance, have developed a 6point Likert questionnaire that covers twelve behavioral aspects of a mentor. Similarly, there are value-added assessments to measure teachers' effectiveness. These instruments could be applied to measure mentoring and teaching effectiveness after the proposed PD. We argue that the PD framework can be deployed in this way in a variety of contexts, and that the resulting research will positively contribute to mentoring programs around the world.

\section{References}

Adams, P.E., \& Krockover, G.H. (1997). Beginning science teacher cognition and its origins in the preservice secondary science teacher program. Journal of Research in Science Teaching, 34(6), 633-653.

Adler, J. (2000). Social practice theory and mathematics teacher education: A conversation between theory and practice. Nordic Mathematics Education Journal, 8(3), 31-53.

Ali, M. A. (1996). On becoming a mentor: Influences on teachers' construction of their identities as mentors. (Doctoral dissertation). Available from ProQuest Dissertations and Theses Database. (UMI No.9706442)

Andrabi, T., Khan, S., Khan, Y., \& Naseer, M. F. (2012). Learning in public schools. London, UK: International Growth Center. Retrieved January 30, 2014 from

http://www.theigc.org/sites/default/files/Andrabi\%20et\%20al_Learning \%20in\%20public\%20schools_Final_0.pdf

Andrews, B. D. \& Quinn, R. J. (2005). The effects of mentoring on firstyear teachers' perceptions of support received. The Clearing House, 78(3), 110-116.

Athanases, S. Z., \& Achinstein, B. (2003). Focusing new teachers on individuals and low performing students: The centrality of formative 
assessment in the mentor's repertoire of practice. Teachers College Record, 105(8), 1486-1520.

Ball, D. L., \& Cohen, D. K. (1999). Developing practice, developing practitioners: Toward a practice-based theory of professional education. In L. Darling-Hammond \& G. Sykes (Eds.), Teaching as the learning profession: Handbook of policy and practice (pp. 3-31). San Francisco: Jossey Bass.

Bell, B., \& Gilbert, J. (1996). Teacher development: A model from science education. Washington, D.C: Falmer Press.

Berk, R. A., Berg, J., Mortimer, R., Moss, B.W., \& Yeo, T. (2005). Measuring the effectiveness of faculty mentoring relationships. Academic Medicine, 80 (1), 66-71.

Boreen, J. \& Niday, D. (2000). Breaking through the isolation: Mentoring beginning teachers. Journal of Adolescent \& Adult Literacy 44(2), 152-163

Borg, M. (2004). The apprenticeship of observation. ELT Journal, 58(3), 274-276.

Borko, H. (2004). Professional development and teacher learning: Mapping the terrain. Educational Researcher, 33(3), 3-15.

Britzman, D. (1986). Cultural myths in the making of a teacher: Biography and social structure in teacher education. Harvard Educational Review, 56 (4), 442-472.

Bullough Jr, R. V. (2009). The continuing education of teachers: Inservice training and workshops. In L.J. Saha, A.G. Dworkin (eds.), International Handbook of Research on Teachers and Teaching, pp.159-169.

Cherian, F. (2007). Learning to teach: Teacher candidates reflect on the relational, conceptual, and contextual influences of responsive mentorship. Canadian Journal of Education, 30 (1), 25-46.

Carver, C. L., \& Katz, D. S. (2004). Teaching at the boundary of acceptable practice: What is a new teacher mentor to do? Journal of Teacher Education, 55(5), 449-462. 
Clark, C. M. (1992). Teachers as designers in self-directed professional development. In A. Hargreaves and M. G. Fullan (Eds). Understanding teacher development, (pp. 75- 84), New York, USA: Teachers College Press.

Clarke, A. (2001). Characteristics of co-operating teachers. Canadian Journal of Education, 26(2), 237-256.

Crutcher, P. A., \& Naseem, S. (2015). Cheerleading and cynicism of effective mentoring in current empirical research. Educational Review 68(1), 40-55.

Darling-Hammond, L. (2010). Evaluating teacher effectiveness: How teacher performance assessments can measure and improve teaching. Washington, DC: Center for American Progress. Retrieved on February 5, 2015 from http://files.eric.ed.gov/fulltext/ED535859.pdf

Darling-Hammond, L. (2009). Teacher education and the American future. Charles W. Hunt Lecture. Presented at the annual meeting of the American Association of Colleges for Teacher Education, Chicago.

Desimone, L. M. (2009). Improving impact studies of teachers' professional development: Toward better conceptualizations and measures. Educational Researcher, 38, 181-199.

Drago-Severson, E. (2007). Helping teachers learn: Principals as professional development leaders. Teachers College Record, 109(1), 70-125.

Driel, J. H., Beijaard, D. \& Verloop, N. (2001). Professional development and reform in science education: The role of teachers' practical knowledge. Journal of Research in Science Teaching, 38(2), 137-158

Feiman-Nemser, S. (1998).Teachers as teacher educators. European Journal of Teacher Education, 21(1), 63-74.

Feiman-Nemser, S. (2001a). Helping novices learn to teach: Lessons from an exemplary support teacher. Journal of Teacher Education, 52(1), 17-30.

Feiman-Nemser, S. (2001b). From preparation to practice: Designing a continuum to strengthen and sustain teaching. Teachers College Record, 103(6), 1013-1055. 
Feiman-Nemser, S. (2003). What new teachers need to learn: Keeping good teachers. Educational Leadership, 60 (8), 25-29.

Fletcher, S. (2000). Mentoring in schools: A handbook of good practice. USA: Stylus Publishing Inc.

Francis, D. (1995). The reflective journal: A window to preservice teachers' practical knowledge. Teaching and Teacher Education, 11(3), 229-241.

Grossman, P. (2008). Responding to our critics: From crisis to opportunity in research in teacher education. Journal of Teacher Education, 59, 10-23.

Guskey, T. R. (1986). Staff development and the process of teacher change. Educational Researcher, 15(5), 5-12.

Guskey, T. R. (2000). Evaluating Professional Development. Thousand Oaks, California: Corwin Press, Inc.

Gustafson, B., Guilbert, S., \& MacDonald, M. (2002). Beginning elementary science teachers: Developing professional knowledge during a limited mentoring experience. Research in Science Education ,32 (3), 281-302

Hargreaves, A., \& Fullan, M. G. (Eds). (1992). Understanding teacher development. New York, NY: Teachers College Press.

Harrison, J., Dymoke, S., \& Pell, T. (2006). Mentoring beginning teachers in secondary schools: An analysis of practice. Teaching and Teacher Education, 22, 1055-1067.

Ingersoll, R., \& Strong, M. (2011). The impact of induction and mentoring programs for beginning teachers: A critical review of the research. Review of Educational Research, 81(2), 201-233.

Kardos, S. M., Johnson, S. M, Peske, H. G., Kauffman, D. \& Liu, E. (2001). Counting on colleagues: New teachers encounter the professional cultures of their schools. Educational Administration Quarterly, 37 (2), 250-290.

Korthagen, F., Loughran, J., \& Russell, T. (2006). Developing fundamental principles for teacher education programs and practices. Teaching and Teacher Education, 22, 1020-1041. 
Latta, M. M., \& Field, J. C. (2005). The flight from experience to representation: Seeing relational complexity in teacher education. Teaching and Teacher Education, 21, 649-660.

Lave, J., \& Wenger, E. (1991). Situated learning: Legitimate peripheral participation. Cambridge, UK: Cambridge University Press.

Little, J. W. (2002). Locating learning in teachers' communities of practice: Opening up analysis in records off everyday work. Teaching and Teacher Education, 18, 917-946.

Luft, J. A. (2009) Beginning secondary science teachers in different induction programmes: The first year of teaching. International Journal of Science Education, 31(17), 2355-2384, DOI: 10.1080/09500690802369367

Lumer, C. (2010). What is practical knowledge? In M. DeCaro \& R. Egidi (Eds.) The architecture of knowledge, epistemology, agency, and science. Rome: Carocci.

Mills, H., Moore, D., Keane, W.G. (2001). Addressing the teacher shortage: A study of successful mentoring programs in Oakland County, Michigan. Clearing House, 74(3), 124-26.

Moir, E. (2010). Defining, measuring, and articulating the impact of effective teacher induction. Reflections, 12 (1), 3-15.

Moir, E., D. Barlin, J. Gless, \& J. Miles (2009). New teacher mentoring: Hopes and promises for improving teacher effectiveness. Cambridge, MA: Harvard Education Press.

Orland, L. (2001). Reading a mentoring situation: One aspect of learning to mentor. Teaching and Teacher Education, 17, 75- 88.

Ottesen, E. (2007). Teachers "in the making": Building accounts of teaching. Teaching and Teacher Education, 23, 612-623.

Santrock, J. W. (2013). Case studies in educational psychology. McGraw-Hill. Retrieved September 2, 2013 from http://highered.mcgraw-

hill.com/sites/dl/free/0070909695/120222/educational.pdf

Schwille, S. A. (2008). The professional practice of mentoring. American Journal of Education, 115(1), 139-167. 
Segall, A. (2002). Disturbing practices: Reading teacher education as text. New York: Peter Lang.

Schneider, R. (2008). Mentoring new mentors: Learning to mentor preservice science teachers. Journal of Science Teacher Education, 19, 113-116.

Sherin, M. G \& van Es., E. A. (2009). Effects of video club participation on teachers' professional vision. Journal of Teacher Education, 60(1), 20-37.

Stanulis, R. N. (1994). Fading to a whisper: One mentor's story of sharing her wisdom without telling answers. Journal of Teacher Education, 45(1), 31-37.

Stanulis, R. N., \& Ames, K. (2009). Learning to mentor: Evidence and observation as tools in learning to teach. The Professional Educator, 33(1), 28-38.

Stanulis, R. N., \& Floden, R. (2009). Intensive mentoring as a way to help beginning teachers develop balanced. Journal of Teacher Education, 60(2), 112-122.

Stigler, J. W., \& Hiebert, J. (2004). Improving mathematics teaching. Educational Leadership, 61(5), 12-17.

Ward, B. A., \& Tikinoff, W. J. (1976). An interactive model of research and development in teaching (Report 76-1). San Francisco: Far West Laboratory for Educational Research and Development.

Windschitl, M., Thompson, J., \& Braaten, M. (2009). The beginner's repertoire: Proposing a core set of instructional practices for teacher preparation. DR K-12 Meeting, National Science Foundation.

Woloszyk, C. A. (1992). A study of school climate in a secondary professional development school. ERIC. Retrieved September 2, 2013 from http://eric.ed.gov/?id=ED346026

Zeichner, K. (2010). Rethinking the connections between campus courses and field experiences in college- and university-based teacher education. Journal of Teacher Education, 61(1-2), 89-99.

Received on: February 21, 2016

Revised on: May 20, 2016

Accepted on: June 07, 2016 